\title{
Japan Society of Business Administration (JSBA)
}

\author{
Shinshi Kataoka
}

\author{
Chairman, JSBA \\ Department of Business Administration, Momoyama Gakuin University, 1-1 Manabino, \\ Izumi-city, Osaka, Japan. \\ E-mail: skataoka@andrew.ac.jp; Website: http://wwwsoc.nii.ac.jp/jsba/index.html
}

Asian Business \& Management (2002) 1, 287-289. doi:10.1057/palgrave.abm.9200024

With 2002 marking the 76th year since its foundation, the Japan Society of Business Administration (JSBA) is one of the oldest social science associations in Japan. It represents its home country in the field of business and management studies and is also Japan's largest society in its field. Its principal aims involve the furtherance of research and diffusion of business and commercial studies, the facilitation of collaboration and socialization between researchers, and the opportunity for networking between societies and groups in Japan and overseas.

Its inaugural convention was held in Tokyo in November 1926, at the Tokyo Commercial University (now Hitotsubashi University), at which 207 professors and 135 businessmen gathered under the chairmanship of Professor Ueda Teijirou of the same university. Beginning with these 342 members, the society passed the 2000 mark in 1994 and, as of September 2001, had reached a membership of 2133, including 19 from overseas. The institutions to which its members are affiliated include 277 universities, 99 junior colleges, five vocational schools, 24 foreign universities and 56 private enterprise groups, along with 56 businessmen. The Society is therefore strongly characterized as an association of business studies and commercial studies teachers, centred on universities and junior colleges, a make-up influenced from its early days by its association with the Society of University Teachers of Business Administration in Germany, founded in 1921. The establishment of business administration departments at universities all over the country and the dramatic rise in the number of university academic staff and researchers that went hand-in-hand with the post-war high growth of the Japanese economy, particularly in the 1960 s, has been a factor in the increase in membership that can be seen today.

The Society effectively functions as an umbrella organization in which almost all of those who teach or research business administration participate. Most members, as well as being affiliated to JSBA, are also affiliated to other 
smaller societies in fields such as business history, organization, comparative management, managerial engineering, labour, finance, commerce, management education, office automation, management philosophy, business ethics, small and medium enterprises and Asian management. Many of these smaller societies gradually came into being from the 1960s onwards, founded by JSBA members looking to pursue more specialized research.

Within the JSBA, local chapters have gradually been established since its foundation, and include the six chapters of Kanto (established in 1926) with 903 members at present, Kansai (1927) with 558 members, Kyushu (1958) with 174 members, Hokkaido (1958) with 96 members, Chubu (1962) with 276 members and Tohoku (1974) with 107 members. Each chapter regularly holds between five and 10 seminars each year.

The officials of the Society comprise board chairman, eight standing board members, about 30 regular board members (including the chairman and standing members), two auditors and 10 officers. The Society was, in the initial period after its foundation, run by a council system of five board members under Ueda Teijirou. After that, however, the board chairman system was introduced, and to date this position has been held by Takitani Zenichi, Hirai Yasutarou, Takase Soutarou, Kobayashi Yoshimoto, Ichihara Kiichi, Mouri Shigetaka, Kaidou Susumu, Tajima Moriyuki, Mori Akio, Noguchi Tasuku and Kataoka Shinshi. The head office has always remained at Hitotsubashi University.

Once a year, the Society holds a 4-day conference of in-depth discussions on appropriate topical themes, at which 10-12 participants deliver reports. There are in addition between two and four workshops and ordinary sessions in which around 60 presentations are made, as well as the display of various exchange papers.

Before the war, themes for discussion centred on methodologies of business studies, corporate forms, company systems, corporate centralization, allocation, distribution, trade and accounting. After the war, however, the focus shifted to business management, decision-making, marketing, production control, research and development, technological innovation, personnel management, financial management and management in general. Most recent themes have been on business strategies, M \& A, organization, multinational corporations, globalization and IT.

The Society publishes a collection of the papers presented to the conference as a single annual volume; it is distributed free of charge to members, and is also available for general sale. In addition, the twice-yearly bulletin Journal of Business Management has also been published since April 1997. These are all Japanese-language publications, but brief English summaries are attached. A recent development, to take account of the rise of international exchange and the need to publish full papers in English, is the decision to affiliate with 
the newly launched international journal from Palgrave-Macmillan, Asian Business \& Management.

The Society already has a long history of exchange arrangements with the Society of University Teachers of Business Administration in Germany, dating from its formative period, but it has also recently sent representatives to the International Federation of Scholarly Associations of Management (IFSAM), the Academy of Management in the USA, and to the Korean Academic Society of Business Administration (KASBA). The JSBA has played a particularly important role as a founding member of IFSAM for its establishment, with the first World Congress being held in Tokyo in 1992.

In the future, we look forward to continuing our international academic exchange through IFSAM, and supplementing this medium with bilateral exchange with societies from neighbouring Asian countries. 